\title{
An Experimental Study on Using Laser for Cleaning Metal Threads
}

\author{
Neama A. Shehata ${ }^{1}$, Mohamed A. Marouf², Badawy M. Ismail ${ }^{3}$ \\ ${ }^{1}$ Department of Archeology Restoration, Sohag National Museum, Ministry of Tourism and Antiquities, Sohag, Egypt \\ ${ }^{2}$ Conservation Department, Faculty of Archaeology, Sohag University, Sohag, Egypt \\ ${ }^{3}$ Conservation Department, Faculty of Archaeology, Luxor University, Luxor, Egypt \\ Email: *neama.adelazeem@yahoo.com, ${ }^{\star}$ neamaabdelazeem@gmail.com
}

How to cite this paper: Shehata, N.A., Marouf, M.A. and Ismail, B.M. (2020) An Experimental Study on Using Laser for Cleaning Metal Threads. Journal of Materials Science and Chemical Engineering, 8, 46-63.

https://doi.org/10.4236/msce.2020.84004

Received: March 6, 2020

Accepted: April 21, 2020

Published: April 24, 2020

Copyright $\odot 2020$ by author(s) and Scientific Research Publishing Inc. This work is licensed under the Creative Commons Attribution-NonCommercial International License (CC BY-NC 4.0).

http://creativecommons.org/licenses/by-nc/4.0/

\begin{abstract}
Samples of metal threads were prepared, underwent artificial aging, and cleaned using laser applications to define the efficiency of cleaning that gives the best results without affecting the components of the thread, including metal, fibers, or dyes. The present study aimed to investigate and evaluate laser cleaning of the corroded metal embroidery, revealing the chemical composition of the corrosion and prop and evaluating the effects of laser cleaning on the surface of the metal threads. It utilized SEM and LM to provide morphological information about the surface and the cleaning effect. Moreover, SEM-EDX was used to define the elemental composition, and XRD was employed to offer information on the metal. The restoration of cultural heritage depends on defining the devastating changes to the man-made pieces. It compares pre-and post-restoration conditions of the object (e.g. painting, photography, and material analysis), controlling the conditions that are almost irrevocable. An Interval Digital Macro-photography is employed to control the corrosion PS tests for a long period of museum exhibition [1].
\end{abstract}

\section{Keywords}

Experimental, Laser, Corrosion, Cleaning, Metal Threads

\section{Introduction}

\subsection{Nature of the Metal Threads}

Metal threads, as a term, refer to thin, yarn-like textile decorations (strips and wires) made of solid metal. They are a metal-coated organic material or the combination of these with natural or man-made fibers [2]. Metals can be transformed into threads like those ones used in textiles. Therefore, metal threads are 
sometimes classified as fibers. Moreover, gold and silver alloyed with baser metals such as copper are the most common materials used for metal thread production [3]. Early metal threads were thin strips of gold cut from a beaten metal foil and directly woven or embroidered into textiles. Later, they were wound around a fibrous core of silk dyed according to the metal wrapping color, making the thread's uses more versatile [4].

\subsection{Mechanisms of Metal Threads' Corrosion}

Corrosion is one of the most common problems causing the degradation of the metal threads and the textile samples. Corrosion crusts are a mixture of a number of corrosion products with impurities from the surroundings. They cause gradual degradation to the thread surface to become brittle and less shiny. Furthermore, they result in changes to the threads and the textile in embroidered ornament parts and fibers [5]. Some artifacts containing copper or silver largely have many natural and artificial forms of corrosion [6]. Corrosion is an undesirable degradation resulting from the interactions of materials with the surrounding environment. Some forms are not often clear [7]. Hence, it is a natural reflection of the metal to create a case of balance with the environment [8]. It results from the devastating chemical interaction between the metal and the environment [9]. Corrosion science is concerned with returning the metal artifacts or objects to the original case with the least intervention [10]. They are affected, in extreme weather conditions, with natural and artificial factors. Because metals tend by nature to return to their original case, corrosion is a chemical and electric reaction between the metals and the environment, returning to their oxides. Such interactions cause a gradual change or corrosion of the surface [11]. Furthermore, the artifacts containing metals encounter significant changes through chemical, electrochemical and microbiological processes. Consequently, they tend to the original status. In sulfur-rich environments, the copper turns into copper sulfides. Covellite is often created when having sulfides. In addition, thin layers of cuprite $\left(\mathrm{Cu}_{2} \mathrm{O}\right)$, stannic oxide $\left(\mathrm{SnO}_{2}\right)$, as well as green components, e.g. malachite $\left[\mathrm{Cu}_{2}\left(\mathrm{CO}_{3}\right)(\mathrm{OH})_{2}\right]$ and atacamite $\left[\mathrm{Cu}_{2}(\mathrm{OH})_{3} \mathrm{Cl}\right]$ are formed [12].

Corrosion takes place among granule cells and forms an integrated layer of cuprite $\left(\mathrm{Cu}_{2} \mathrm{O}\right)$ to fill in the gaps. It is joined with the migration of copper ions through the preliminary cuprite layer, forming secondary corrosion products, including cuprite, malachite, and basic copper chlorides. The external corrosion layers often include quartz granules resulting from burial precipitates. Moreover, the differences in burial environments result in additional spaces of different compounds, e.g. sulfates and chlorides [13]. First, copper corrosion causes cuprite as a result of the direct interaction between copper and the dissolved $\mathrm{O}_{2}$ or $\mathrm{H}_{2} \mathrm{O}$ molecules. Cuprite has high electric connectivity and allows transferring copper ions through cuprite layers, allowing copper ions to dissolve in water. In addition, the corrosion of copper bullions in salty environments is much lower than pure copper [14]. The inner layer of corrosion products basically consists of 
$\mathrm{Cu}_{2} \mathrm{O}$, while the inner one comprises $\mathrm{Cu}_{2} \mathrm{O}$ and $\mathrm{CuO}$. The size of the resulting $\mathrm{Cu}_{2} \mathrm{O}$ and $\mathrm{CuO}$ in oxygen environments at a high temperature depends on the thermal use of oxides [15]. The oxidation rate of copper bullion relays on the concentration of its components and the relative spread of atoms or ions in the oxide layers [16]. In terms of corrosion, copper threads are faster than the silver ones. They corrode when interacting with $\mathrm{O}_{2}, \mathrm{H}_{2} \mathrm{~S}$, and $\mathrm{Cl}^{-}$, as follows [17] (see Figure 1):

- With oxygen $\left(\mathrm{O}_{2}\right)$ to form copper $(\mathrm{I})$ oxide $\left(\mathrm{Cu}_{2} \mathrm{O}\right)$, a reddish corrosion layer, and copper (II) oxide ( $\mathrm{CuO})$, a black corrosion layer.

- With hydrogen sulfide $\left(\mathrm{H}_{2} \mathrm{~S}\right)$ to form copper sulfide (CuS), a black non-protective corrosion layer, which is usually mixed with copper (II) oxide.

- With carbon dioxide $\left(\mathrm{CO}_{2}\right)$, in the presence of water, to form basic copper (II) salts on the surface: copper (II) carbonates $\left[\mathrm{CuCO}_{3}-\mathrm{Cu}(\mathrm{OH})_{2}\right]$, green malachite, or $\left[2 \mathrm{CuCO}_{3}-\mathrm{Cu}(\mathrm{OH})_{2}\right.$, blue azurite).

- With sulphur dioxide $\left(\mathrm{SO}_{2}\right)$, nitrogen oxides $\left(\mathrm{NO}, \mathrm{NO}_{2}\right.$, etc.) and other air pollutants, in the presence of water, to form green colored basic copper (II) salts $\left(\mathrm{CuSO}_{4} \cdot \mathrm{Cu}(\mathrm{OH})_{2}, \mathrm{Cu}\left(\mathrm{NO}_{3}\right)_{2} \cdot \mathrm{Cu}(\mathrm{OH})_{2}\right.$, etc. $)$ on the surface.

- With chloride ions $\left(\mathrm{Cl}^{-}\right)$to form copper (I) chloride $(\mathrm{CuCl})$, a greyish-white compound. This is the most damaging of the copper corrosion.

\subsection{Methods of Cleaning Metal Threads}

Cleaning of a composite textile is one of the most complex processes because the different materials may need safe and precise methods [18]. That is, cleaning the

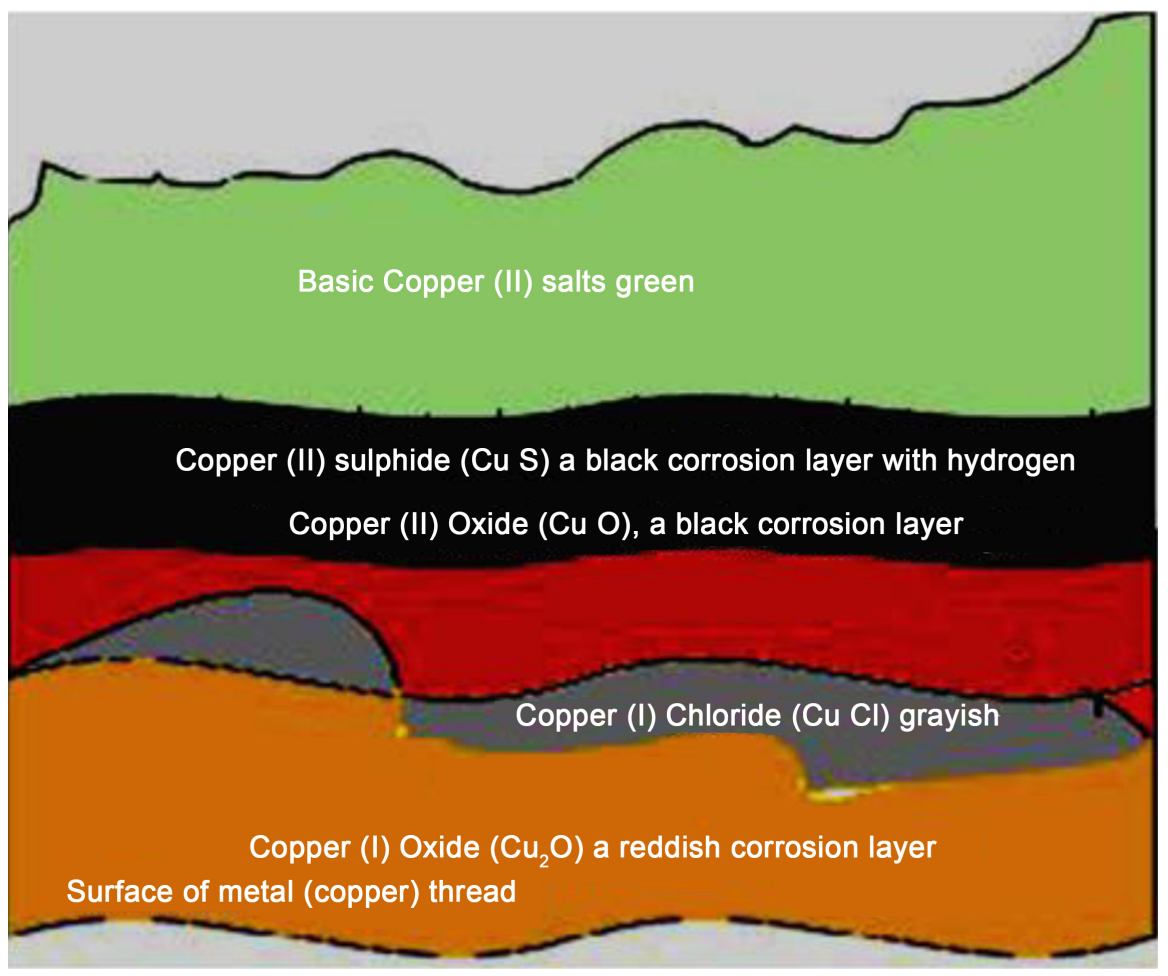

Figure 1. Corrosion layers on the surfaces of copper threads (Marouf, 2009, p. 90) [19]. 
tarnished metal threads made of silver, gilt silver, or copper in textiles is a difficult task, as treatments commonly applied to textile and metals are incompatible [20]. Laser cleaning is an important and acceptable technique because it is effective and safe for archaeological artifacts. It also has more advantages than the traditional methods. Laser cleaning is a selective, non-contact method that leads to acceptable preservation of the surface, unlike the other methods that may cause damage. For example, mechanical cleaning reveals completely and can damage the surface of the decoration. Furthermore, chemical cleaning reacts with the metal decoration [21].

\section{Materials and Methods}

\subsection{Sample Preparation}

The metal thread samples measuring $(15 \mathrm{~cm})$ were prepared. They were copper wires around a cotton yarn in a direction taking (S) shape (see Figure 2-4). In addition, a cotton cloth was prepared. It was embroidered with simple floral motifs using copper wires (see Figure 5 and Figure 6). Photography, Stereo Microscope $^{1}$ (OPTECH, Optical Technology, Germany), and CVM Compact Video Microscope were used at the National Institute of Standards before and after aging and after laser cleaning to define the corrosion products on the metal threads after aging and ascertain the efficiency of laser in removing them.

\subsection{Accelerated Artificial Aging2}

Metal threads degrade and corrode because of different factors, including high and varied relative humidity, air pollutants, and high temperature [22]. Such environmental factors in addition to the volatile organic compounds in the surrounding atmosphere play a major role in the degradation of the artifact [23]. Temperature is the outer manifestation of energy within an object. At higher

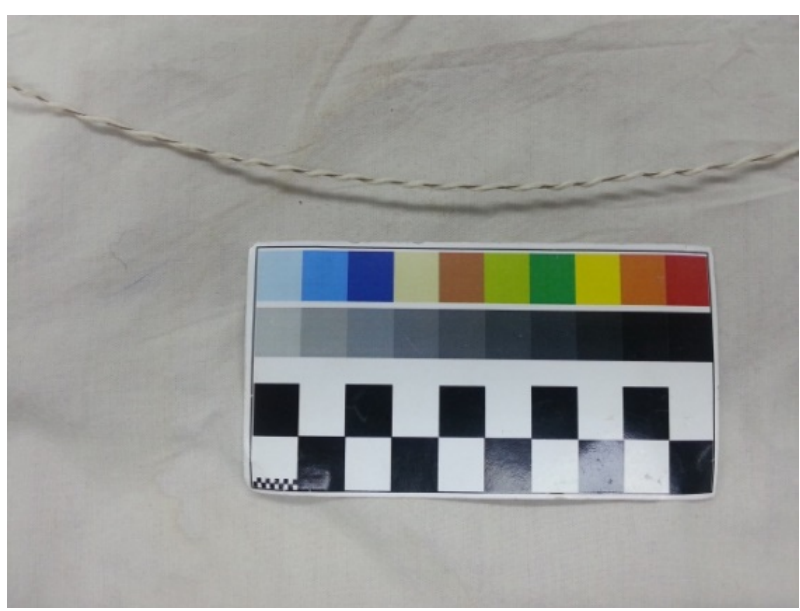

Figure 2. Metallic thread before the artificial aging process.

${ }^{1}$ National institute of standards \& geology department, faculty of science, Sohag university.

${ }^{2}$ The experiments were done according to the specifications of the tissue measurement laboratory, national institute of standards. 


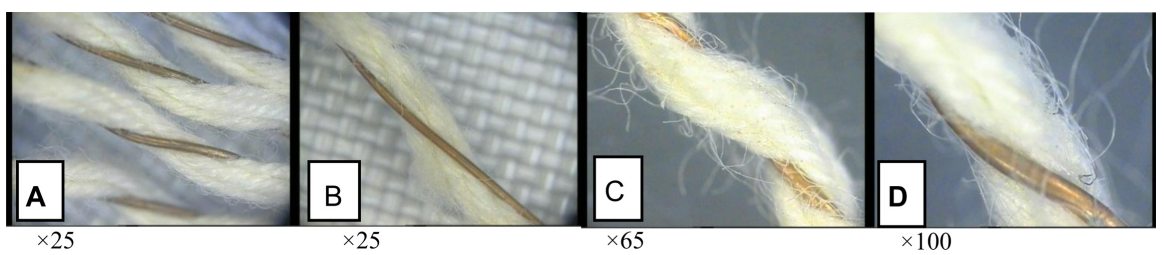

Figure 3. Stereo microscope shows pre-aging metal threads.

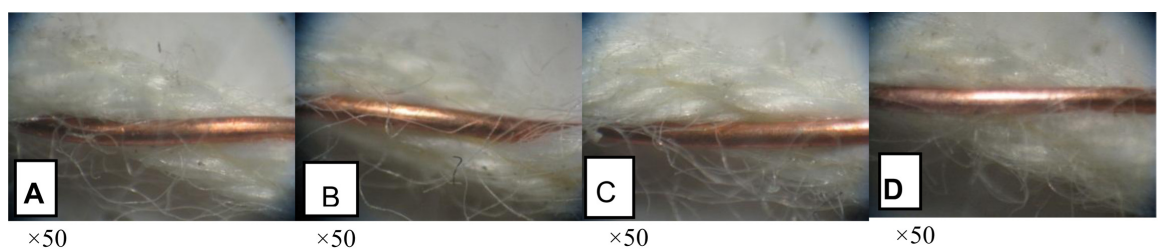

Figure 4. Stereo microscope shows pre-aging metal thread.

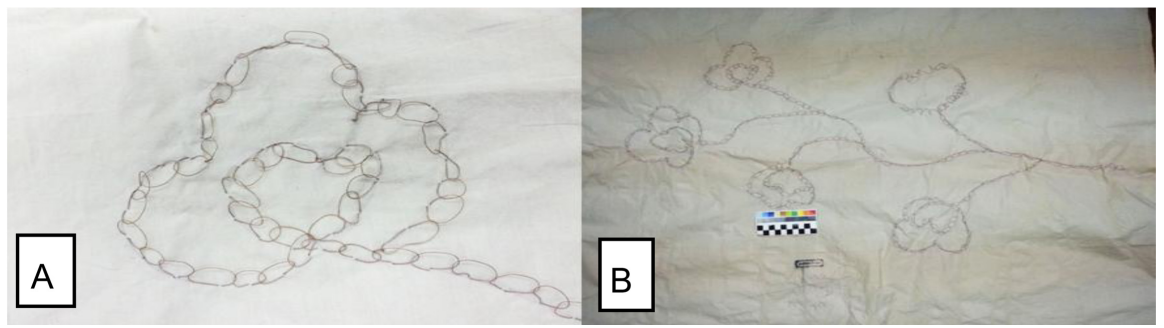

Figure 5. The cloth is embroidered with metal wires before the artificial aging process.

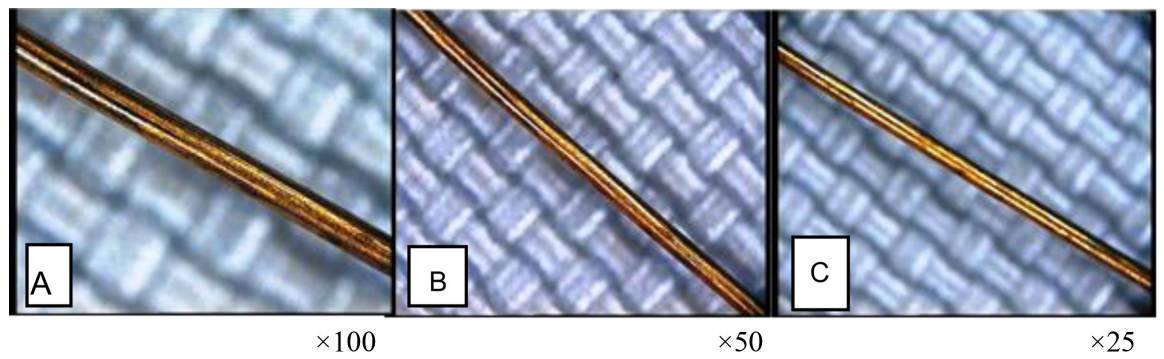

Figure 6. Stereo microscope shows inserting the metal thread in the cloth before aging.

temperatures, atoms and molecules move faster causing quick chemical reactions and increasing the rate of decay. In other words, chemical decay increases with higher temperature or relative humidity. It is related to the absorbed water in organic materials or thermal expansion of inorganic materials, especially metals where the size and shape changes [24]. Moreover, $\mathrm{O}_{2}$ and $\mathrm{CO}_{2}$ form a layer structure of corrosion, and $\mathrm{O}_{2}$ increases metal consumption [25].

The metal thread samples were divided into three groups. The first, second, and third groups were exposed to aging for a week, two weeks, and three weeks, respectively in a thermal oven \{NIS IMI CHM (01)\} after being kept intransparent plastic bags. In addition, $\mathrm{SO}_{2}$ at $60^{\circ} \mathrm{C}$-used in instrument calibration, $\mathrm{NaCl}$ solution (20\%), and $\mathrm{O}_{2}$ were used. The samples were sprayed every two days over the above-mentioned periods. The cotton cloth embroidered with metal threads underwent the same conditions for three weeks. 


\subsection{Laser Cleaning 3}

The experimental copper samples with corrosion layers on the surface underwent the aforementioned deterioration for three weeks.

- First, the experimental samples were displayed before exposure to define the most appropriate and best ways and the typical duration.

- The metal threads were exposed to many laser rays to identify the most appropriate one for application with studying their positive and negative aspects.

- Infrared laser with a wavelength of $1064 \mathrm{~nm}$ was used for the copper samples from 5 to 15 minutes [26].

- Ultraviolet laser with a wavelength of $355-266 \mathrm{~nm}$ was used from 5 to 15 minutes [27].

- Q-Switched Nd:YAG laser with a wavelength of $352 \mathrm{~nm}$ [28] was used from 5 to 15 minutes for the metal threads on cotton yarns exposed for different deterioration manifestations for three weeks were exposed.

\section{Results}

After a week of the accelerated artificial aging, corrosion appeared on the metal threads (see Figure 7). After two weeks, it took the form of clusters (see Figure 8 and Figure 9). After three weeks, corrosion manifestations moved to the fibers (see Figures 10-13).

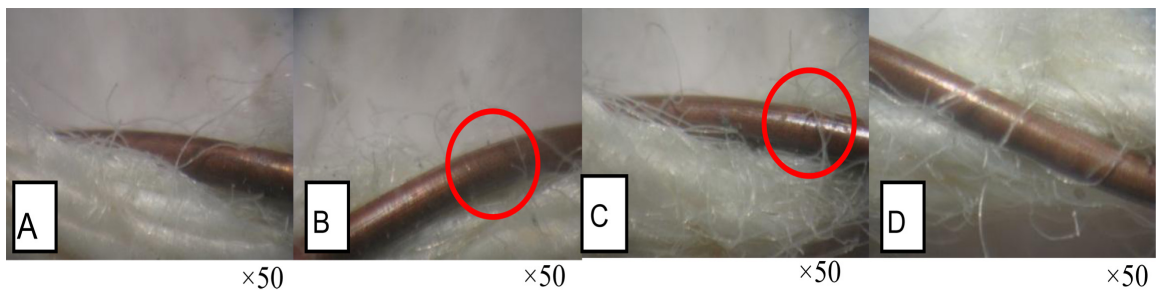

Figure 7. Stereo microscope shows the metal threads after a week of aging and the emergence of corrosion.

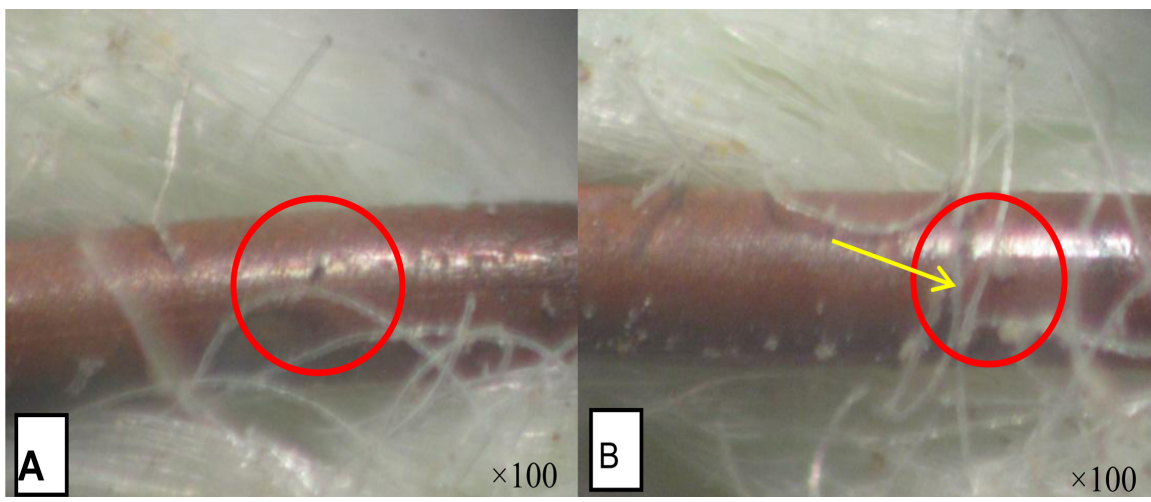

Figure 8. Stereo microscope shows the metal threads after two weeks of aging and the clusters of corrosion.

${ }^{3}$ Laser laboratory, Physics department, faculty of science, south valley university. 


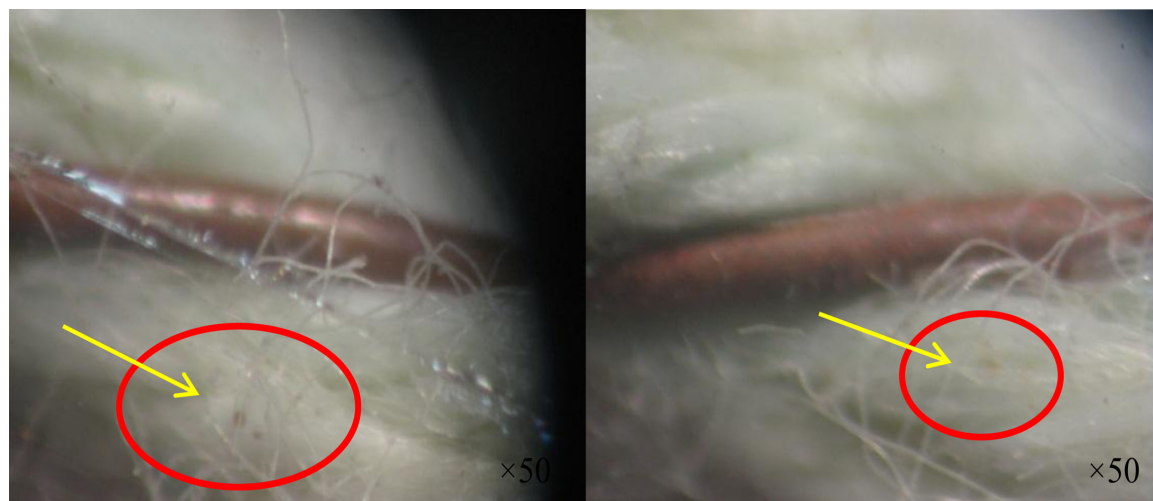

Figure 9. Stereo microscope illustrates the metal threads after two weeks of aging and the manifestations of corrosion on the fibers.

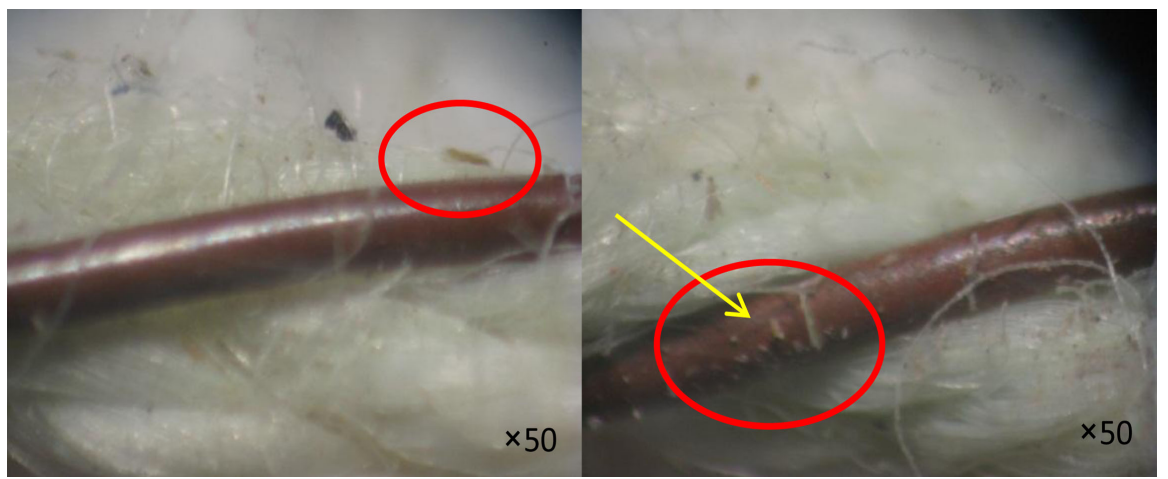

Figure 10. Stereo microscope illustrates the metal threads after three weeks of aging and the clusters of corrosion.

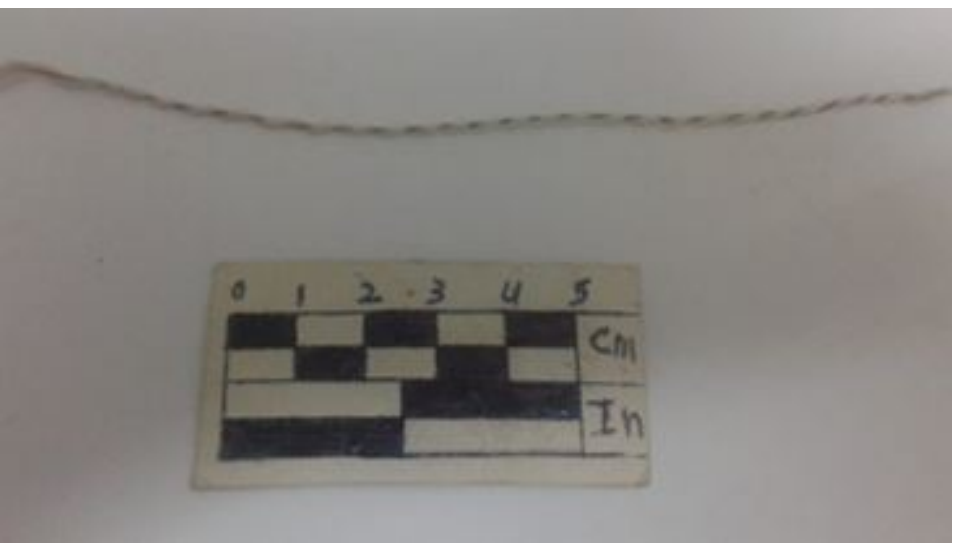

Figure 11. The metallic thread after the artificial aging process.

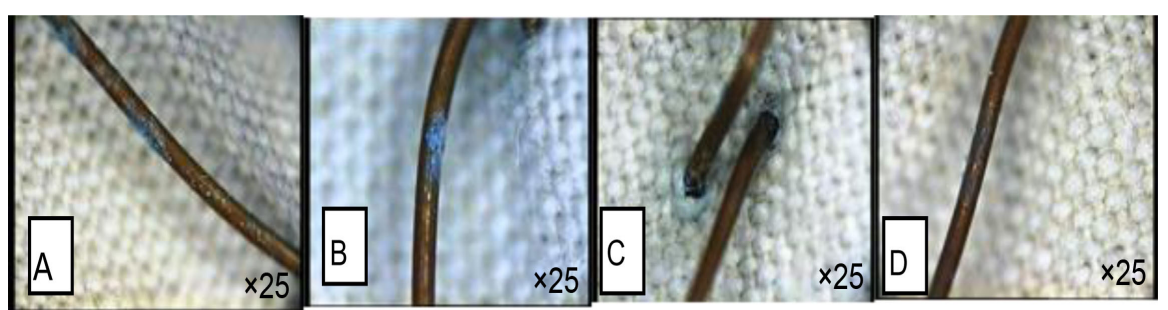

Figure 12. Stereo microscope shows the metal thread in the cloth after aging. 


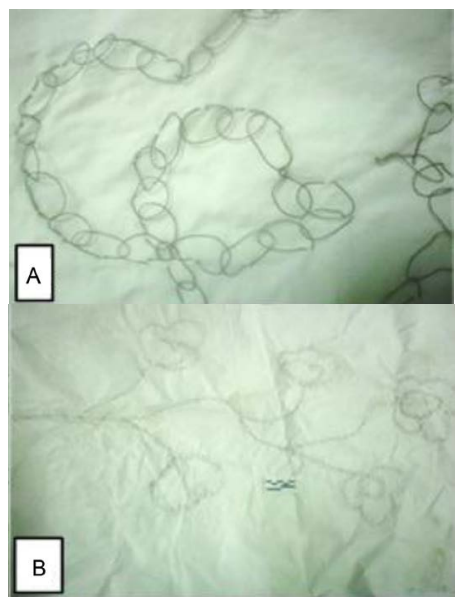

Figure 13. The cloth is embroidered with metal wires after the artificial aging process.

- Using infrared laser with a wavelength of $1064 \mathrm{~nm}$ for the copper samples from 5 to 15 minutes causes somewhat blackness after increasing the temperature of cotton yarns. The high temperature causes a great color change and roast in the case of long periods of exposure [26].

- Using the ultraviolet laser with a wavelength of 355 - $266 \mathrm{~nm}$ from 5 to 15 minutes gave relatively good results. It affected strongly the cotton and dryness and caused the breaking of textile fibers [27].

- Using the Q-Switched Nd:YAG laser with a wavelength of $352 \mathrm{~nm}$ [28] (see Figure 14) from 5 to 15 minutes for the metal threads on cotton yarns exposed for different deterioration manifestations for three weeks gave good and appropriate results. It did not cause severe heating that affects neither the metal threads nor the cotton yarns like the other types (see Figures 15-18). The appropriate period was set, and meticulous notes were taken after repetition. It was set to 15 minutes. After setting the appropriate method and period, it was applied to the embroidered cloth that was exposed to several deterioration factors.

\subsection{Scanning Electron Microscope (SEM-EDX) ${ }^{4}$}

JEOL JSM-5500 LV Scanning Electron Microscope (JEOL, Japan) was used in examining the metal threads (see Figure 19), as well as studying and identifying the morphological structure of corrosion products (see Figure 20). It also helped examine and evaluate the laser cleaning of the corroded metal embroidery and revealing the chemical structure of the crust, corrosion products, and prop. It helped monitor the effects of laser cleaning on the surface of the metal thread (see Figure 21). SEM and Optical Microscope (OP) were utilized to provide morphological information about the surface and the effect of cleaning. SEM-EDX was used to define the elemental structure, while XRD was employed for providing information about the metal.

${ }^{4}$ Central laboratory, south valley university in Qena. 


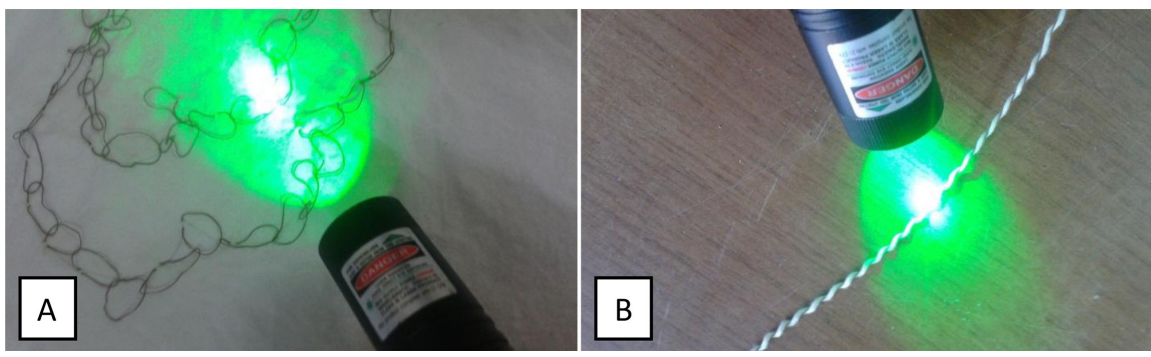

Figure 14. Laser cleaning of the metal threads and the embroidered cloth.

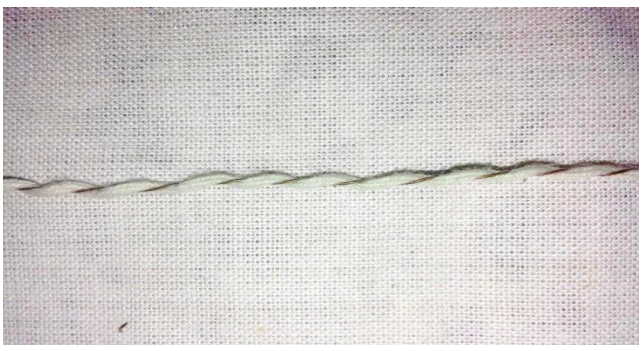

Figure 15. The metal thread after laser cleaning.

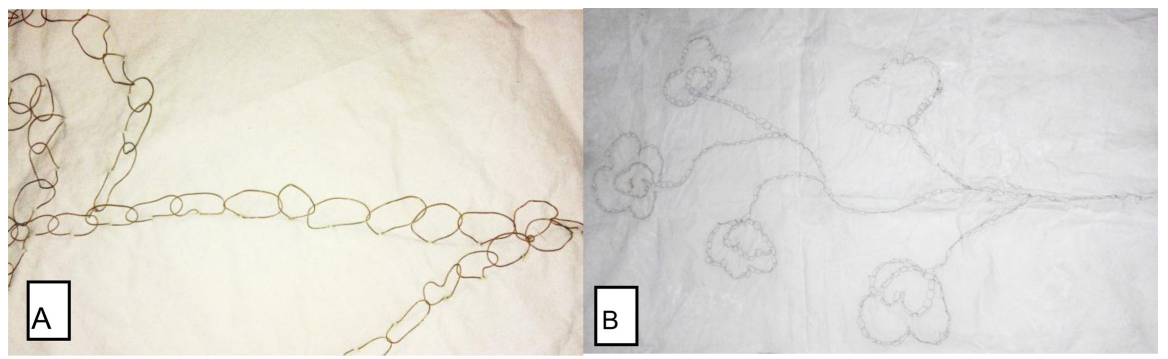

Figure 16. The cloth after laser cleaning.

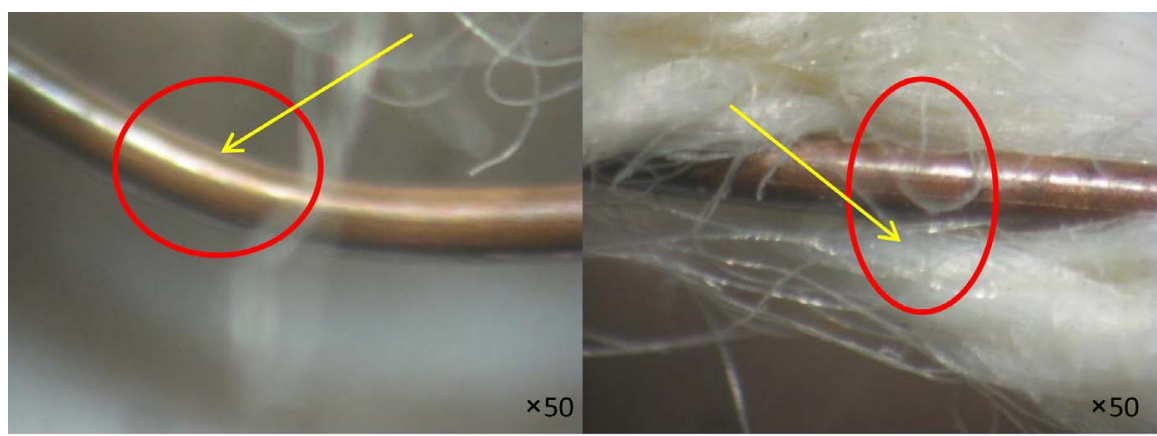

Figure 17. Stereo microscope shows the metal thread after laser cleaning and the effect of laser on the corrosion layers but not the fibers.

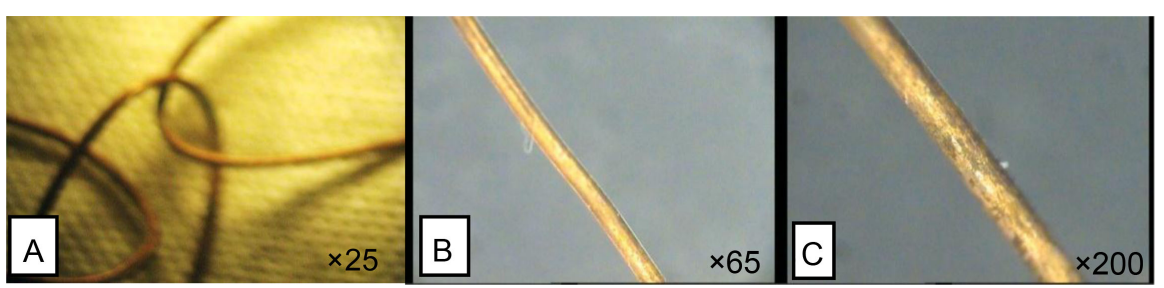

Figure 18. Stereo microscope shows the metal thread in the cloth after laser cleaning. 


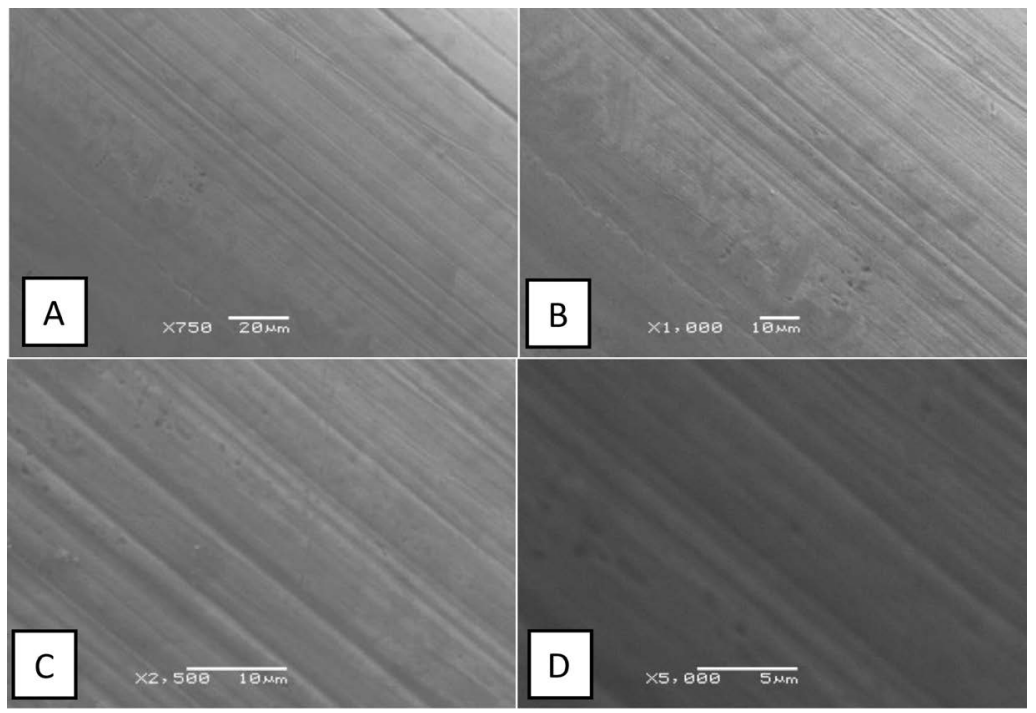

Figure 19. SEM shows a copper sample before aging.

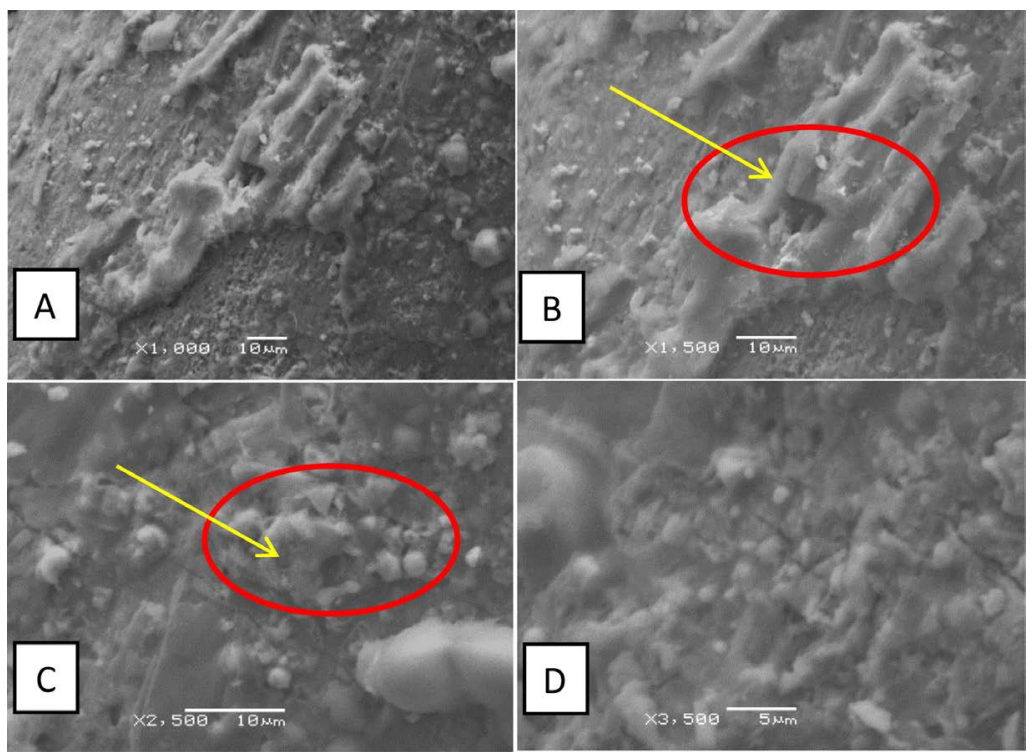

Figure 20. SEM shows a copper sample after aging and corrosion layers on the surface.

\subsection{Results of XRF Analysis 5}

Identifying the chemical composition of all samples and analyzing corrosion samples were carried out using X-ray fluorescence analysis (XRF), JEOL JSX Element Analyzer with Energy Dispersive X-Ray Fluorescence system (EDXRF).

\subsection{Results of XRD Analysis ${ }^{6}$}

XRD Unit, Assuit University, Model PW 1710 control unit Philips, Anode Material Cu, 40 K.V, 30 M.A, 2 Cita from 4 to 60 was used to analyze the samples showing their compounds.

${ }^{5}$ Central laboratory, south valley university in Qena.

${ }^{6} \mathrm{XRD}$ unit, physics department, faculty of science, Assiut university. 


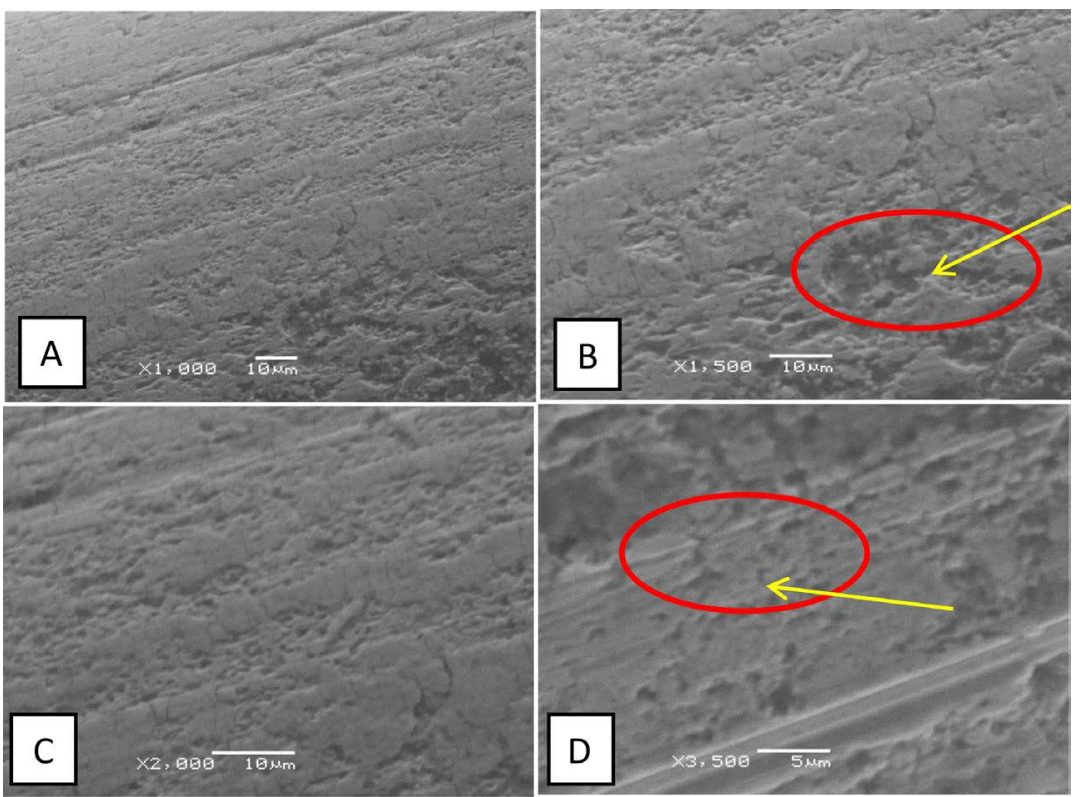

Figure 21. SEM shows a copper sample after laser cleaning and illustrates the effect of laser on the corrosion layers.

\section{Discussion and Conclusion}

\subsection{Discussing the Results of EDX Analysis}

Analyzing the copper sample illustrates that it contained $\mathrm{Cu}(79.89 \%)$ and $\mathrm{O}$ (20.11\%) (see Figures 22-24). After aging and exposure to deterioration factors, it contained $\mathrm{Cu}$ (77.58\%), O (20.07\%), $\mathrm{Cl}$ (1.69\%), $\mathrm{Al}$ (0.28\%), Si (0.21\%), K $(0.12 \%)$, and $\mathrm{Ca}(0.05 \%)$ (see Table 1$)$. There was a difference between the copper samples before and after laser cleaning that affected (see Figure 25 and Figure 26) $\mathrm{Cl}, \mathrm{Al}, \mathrm{Si}$, and $\mathrm{K}$. While $\mathrm{Cu}$ and $\mathrm{O}$ increased to (78.82\%) and (20.08\%), respectively, $\mathrm{Cl}$ decreased to $(0.78 \%)$, and $\mathrm{Al}$ disappeared. In addition, $\mathrm{Si}, \mathrm{K}$, and Ca rated $(0.16 \%),(0.08 \%)$, and $(0.09 \%)$, respectively (see Table 2 ).

\subsection{Discussing the Results of XRF Analysis}

The first sample included a high percentage of $\mathrm{CuO}$ (98.364\%), but $\mathrm{CaO}$ was low (1.637\%) (see Figure 27). The second analysis of a copper sample aged for a week showed that $\mathrm{CuO}, \mathrm{Na}_{2} \mathrm{O}, \mathrm{MgO}, \mathrm{P}_{2} \mathrm{O}_{5}, \mathrm{SO}_{3}, \mathrm{Y}_{2} \mathrm{O}_{3}$, and $\mathrm{Fe}_{2} \mathrm{O}_{3}$ rated (97.689\%), (1.116\%), (0.175\%), (0.259\%), (0.674\%), (0.0363\%), and $(0.036 \%)$ (see Figure 28), respectively. The third analysis of a copper sample aged for three weeks showed $\mathrm{CuO}$ (94.349\%), $\mathrm{Na}_{2} \mathrm{O}$ (2.363\%), $\mathrm{MgO}$ (0.824\%), $\mathrm{P}_{2} \mathrm{O}_{5}$ (0.565\%), $\mathrm{SO}_{3}(0.875 \%)$, and $\mathrm{Fe}_{2} \mathrm{O}_{3}(0.039 \%)$ (see Figure 29). The fourth sample treated was laser showed a high percentage of $\mathrm{CuO}$ (98.172\%), but $\mathrm{CaO}$ was low (1.828\%) (see Figure 30).

\subsection{Discussing the Results of XRD Analysis}

XRD analysis showed copper primarily in addition to other copper oxides indicating corrosion because it is a sample of pre aging thread (see Figure 31). The 


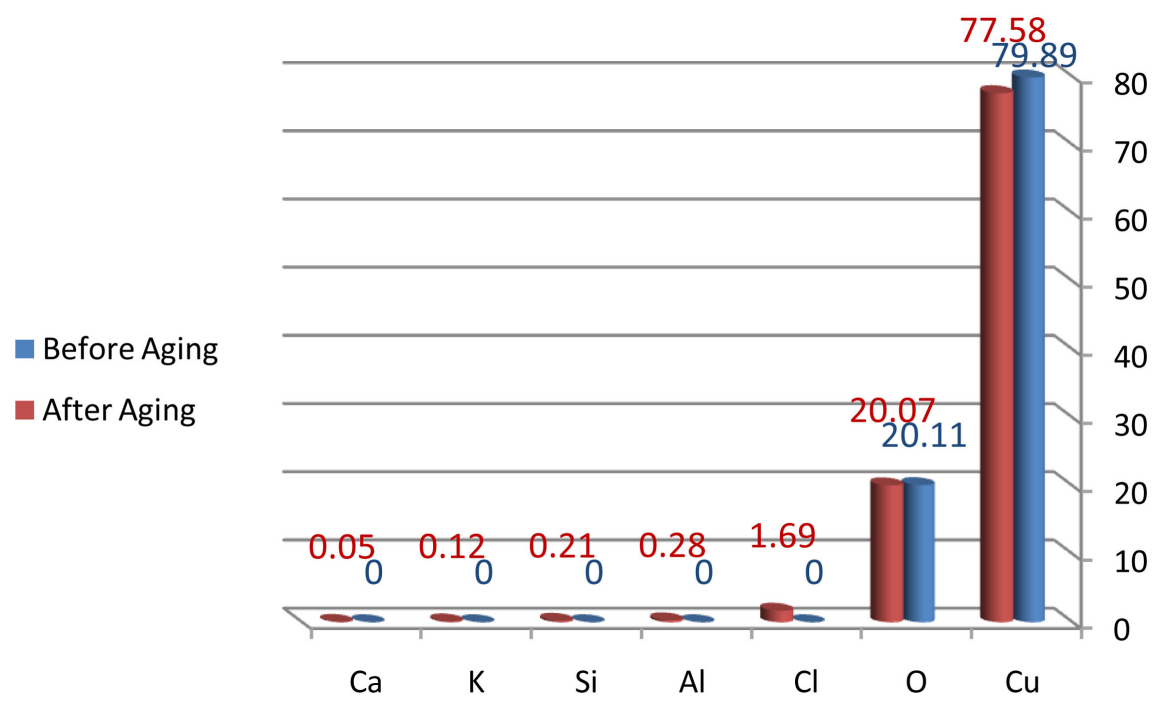

Figure 22. The difference between copper samples before and after aging.

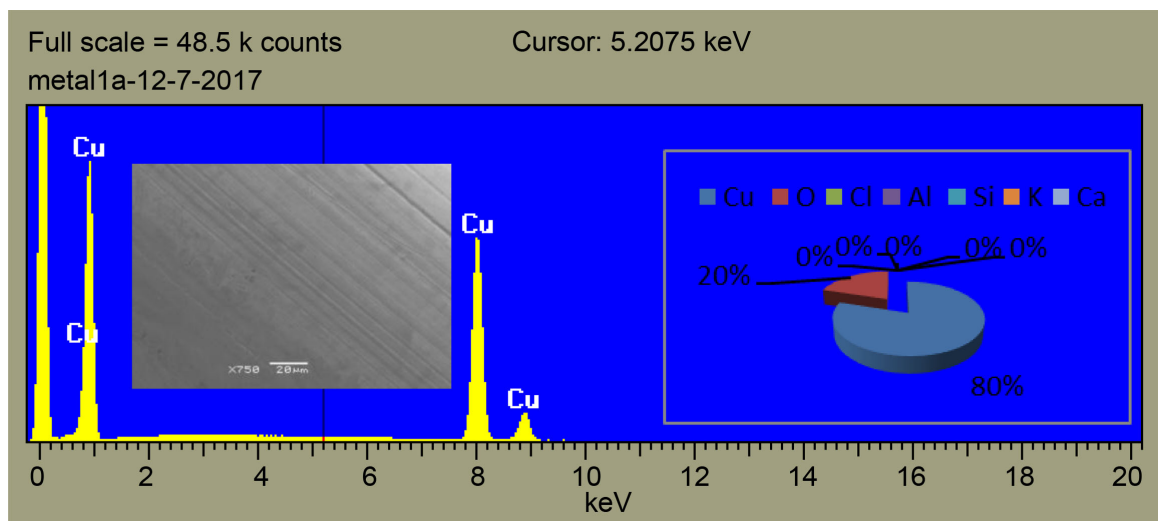

Figure 23. EDX analysis of the copper samples before aging.

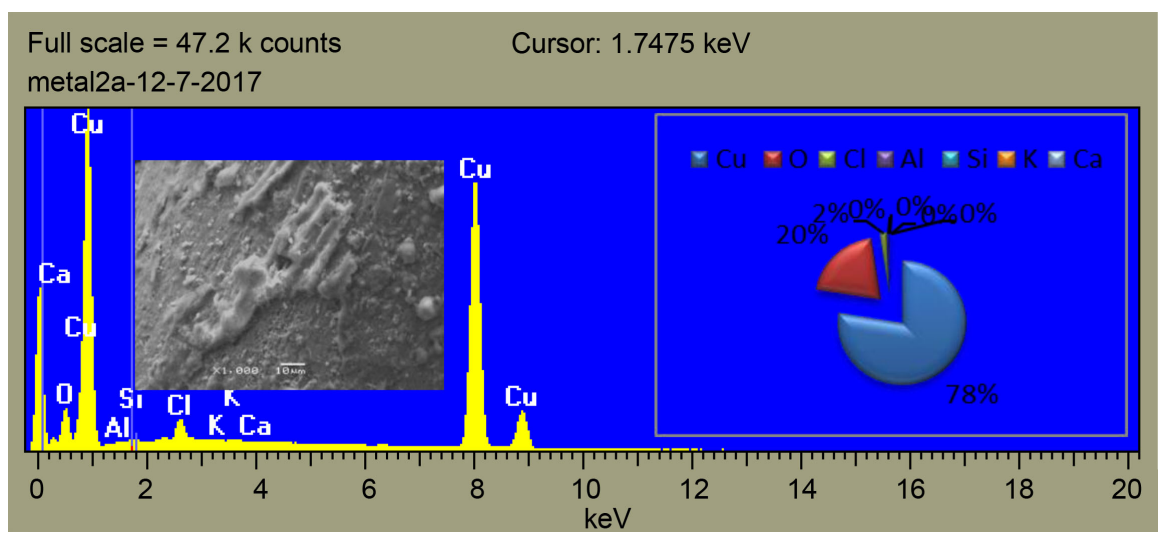

Figure 24. EDX analysis of the copper samples after aging.

second sample contained copper mainly and cuprite representing a surface corrosion layer after the exposure to environmental and laboratory factors (see Figure 32). The third sample of copper threads cleaned by laser showed only copper (see Figure 33), suggesting the efficiency of laser in removing the surface corrosion layer. 


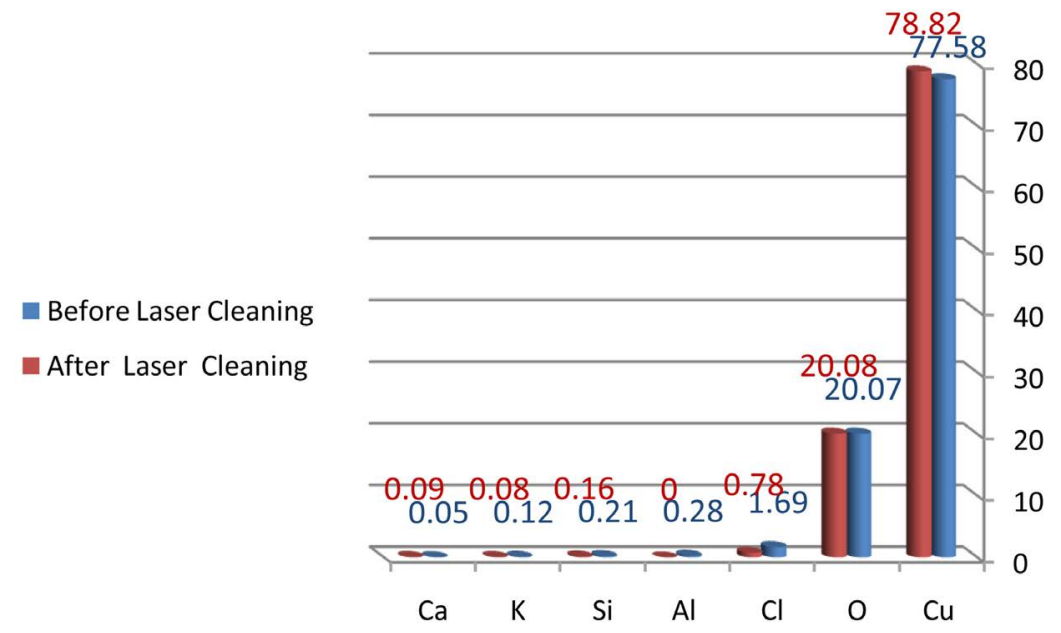

Figure 25. The difference between copper samples before and after laser cleaning.

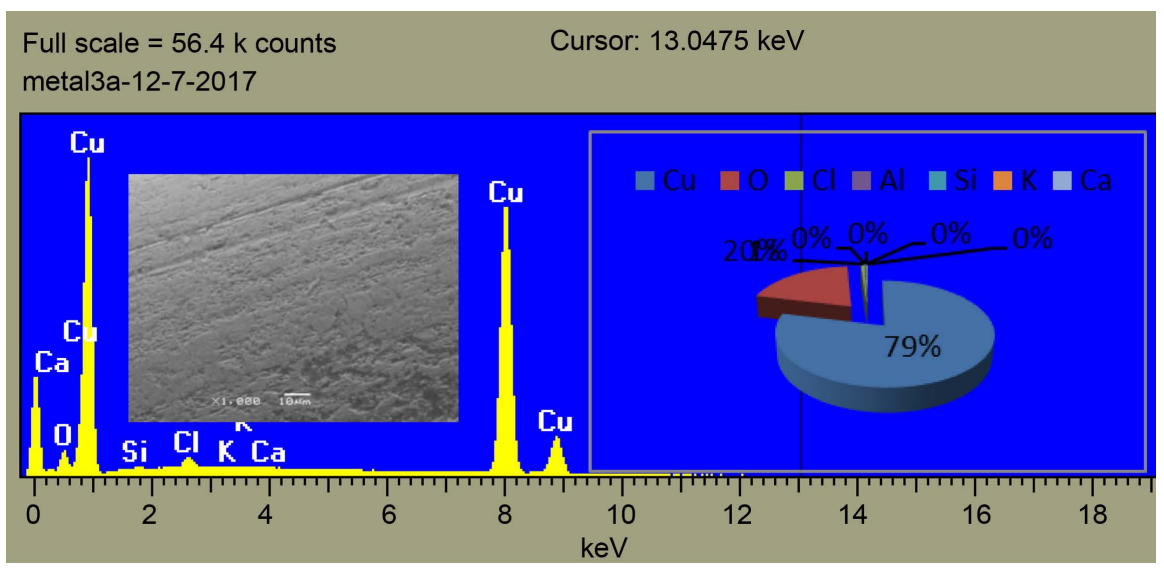

Figure 26. EDX analysis of the copper samples before laser cleaning.

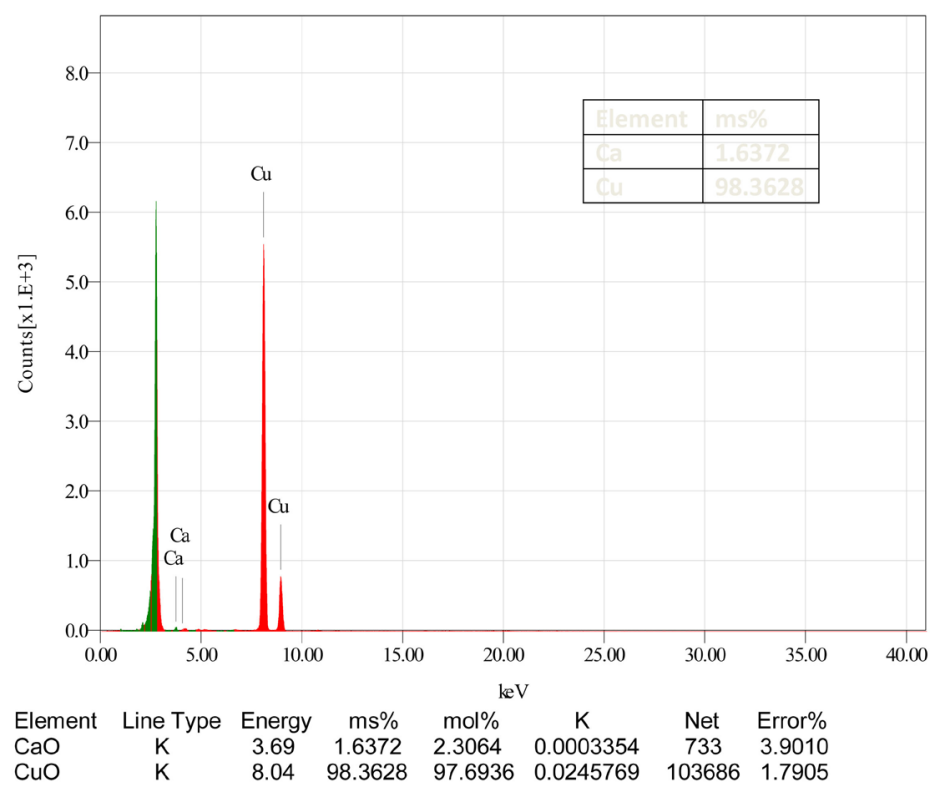

Figure 27. Pre-aging XRF analysis of the copper sample showing copper's rate $(98.4 \%)$. 


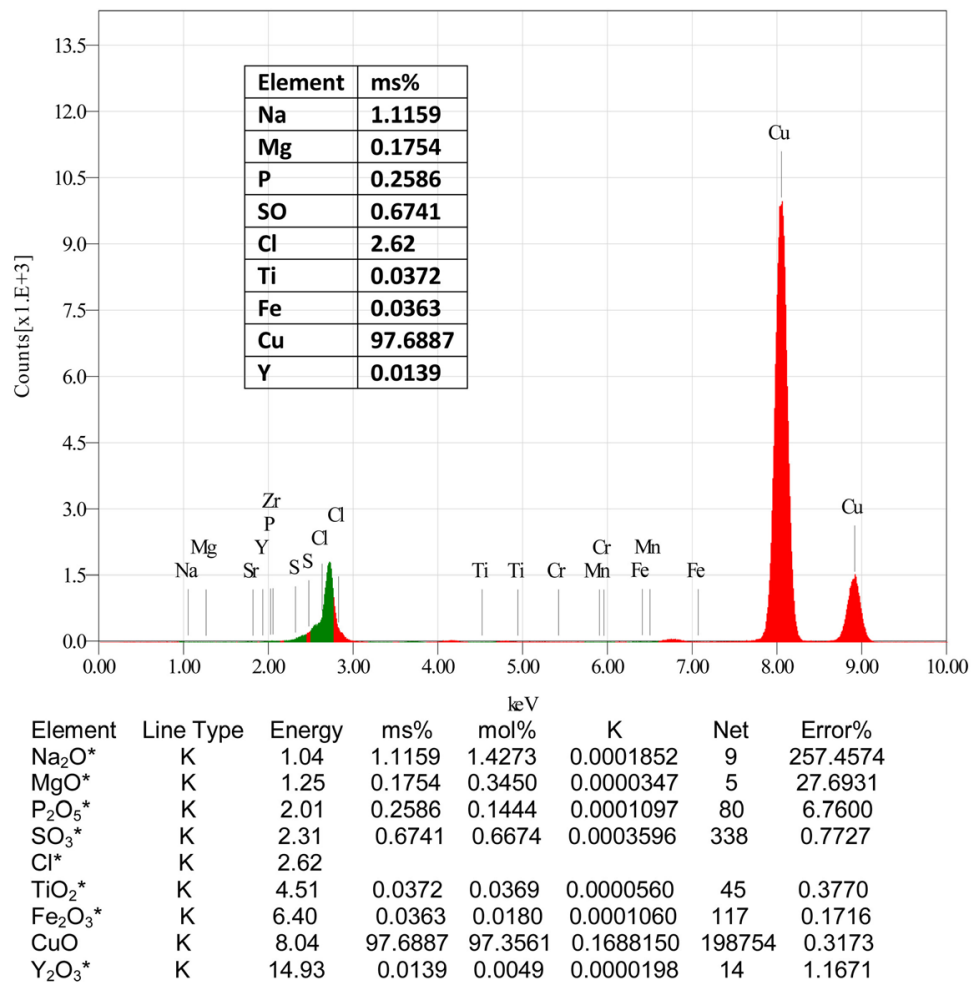

Figure 28. XRF analysis of a copper sample after a week of aging showing many deterioration oxides.

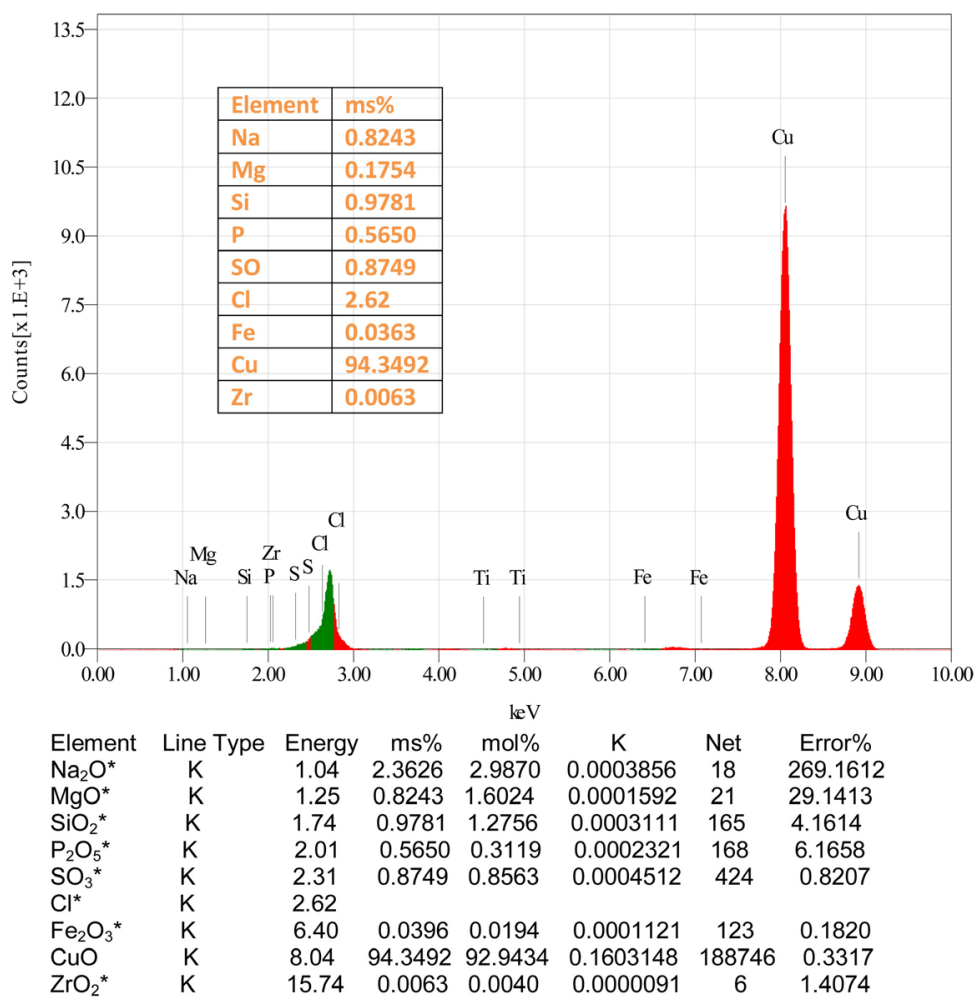

Figure 29. XRF analysis of a copper sample after three weeks of aging showing the increase of deterioration oxides with increased time. 


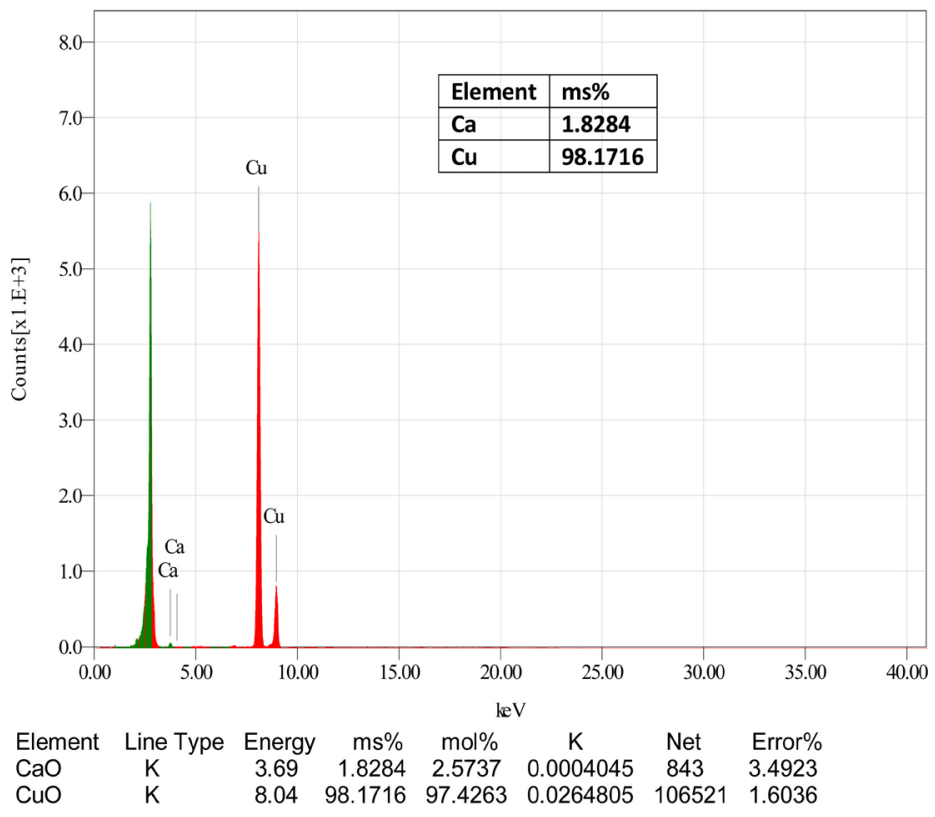

Figure 30. XRF analysis of a copper sample after laser cleaning illustrating the ability of the laser to remove the different corrosion components.

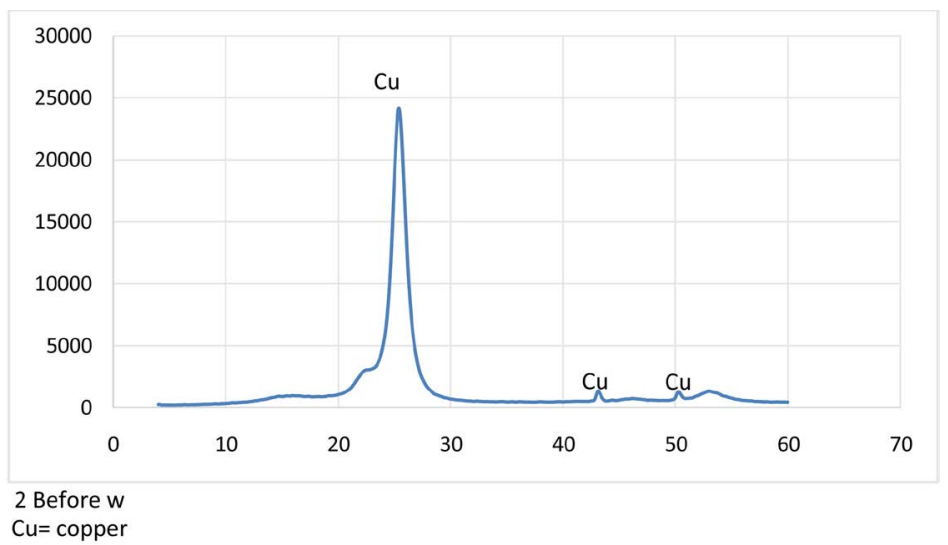

Figure 31. XRD analysis of a pure copper sample illustrates copper as the only metal.

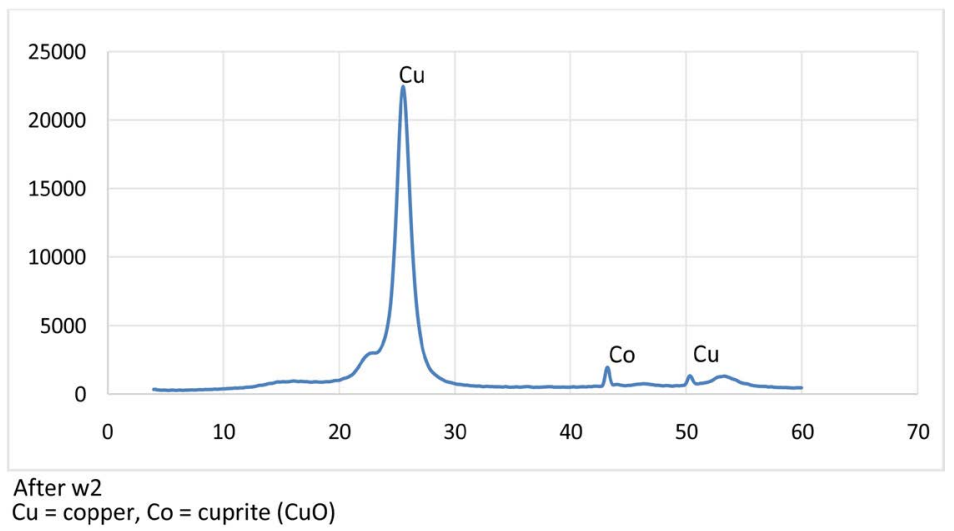

Figure 32. XRD analysis of a copper sample after weathering shows copper and cuprite as deterioration products. 


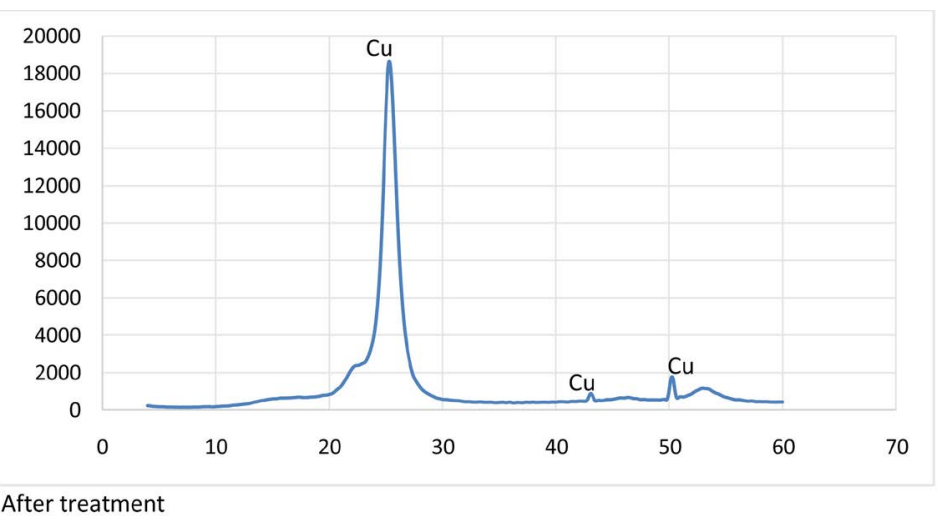

Figure 33. XRD analysis of a copper sample after laser cleaning shows copper only and the removal of cuprite.

Table 1. The difference between copper samples before and after aging and the emergence of $\mathrm{Cl}, \mathrm{Al}, \mathrm{Si}, \mathrm{K}$, and $\mathrm{Ca}$ after aging.

\begin{tabular}{cccc}
\hline Samples & Elements & Before Aging & After Aging \\
\hline & $\mathrm{Cu}$ & 79.89 & 77.58 \\
$\mathrm{O}$ & 20.11 & 20.07 \\
$\mathrm{Cl}$ & 0.00 & 1.69 \\
& $\mathrm{Al}$ & 0.00 & 0.28 \\
& $\mathrm{Si}$ & 0.00 & 0.21 \\
& $\mathrm{~K}$ & 0.00 & 0.12 \\
& $\mathrm{Ca}$ & 0.00 & 0.05 \\
\hline
\end{tabular}

Table 2. The difference between copper samples before and after laser cleaning and its effect on $\mathrm{Cl}, \mathrm{Al}, \mathrm{Si}$, and $\mathrm{K}$ after laser cleaning.

\begin{tabular}{cccc}
\hline Samples & Elements & Before Leaser Cleaning & After Leaser Cleaning \\
\hline $\mathrm{Cu}$ & 77.58 & 78.82 \\
$\mathrm{O}$ & 20.07 & 20.08 \\
$\mathrm{Cl}$ & 1.69 & 0.78 \\
& $\mathrm{Al}$ & 0.28 & 0.00 \\
& $\mathrm{Si}$ & 0.21 & 0.16 \\
$\mathrm{~K}$ & 0.12 & 0.08 \\
& $\mathrm{Ca}$ & 0.05 & 0.09 \\
\hline
\end{tabular}

\section{Conflicts of Interest}

The authors declare no conflicts of interest regarding the publication of this paper.

\section{References}

[1] Crawford, J., et al. (2007) Standardised Remote Monitoring Photographic Capture System (RMPCS) for In-Situ Documentation of Corrosion Protection System Tests. 
Strategies for Saving Our Cultural Heritage, Athens, 85-92.

[2] Járó, M. (2003) Metal Threads in Historical Textiles. In: Molecular and Structural Archaeology: Cosmetic and Therapeutic Chemicals, Springer, Berlin, 163-178. https://doi.org/10.1007/978-94-010-0193-9_15

[3] Bittner, E. (2004) Basic Textile Care: Structure, Storage, and Display. Introduction to the Structure and Technology of Records Materials.

[4] Hacke, A., Carr, C. and Brown, A. (2004) Character of Metal Threads in Renaissance Tapestries. Proceedings of Metal, Canberra, 4-8 October 2004, 415-426.

[5] Radojkouić, B.M., et al. (2015) Determination of Nd:Yag Laser Parameters for Metal Threads Cleaning in Textile Artefacts. Tehnika-Novimaterijali, 24, 209-215. https://doi.org/10.5937/tehnika1502209R

[6] Al-Saad, Z. and Hani, M. (2007) Corrosion Behavior and Preservation of Islamic Silver Alloy Coins. Proceedings the International Conference on Conservation Strategies for Saving Indoor Metallic Collections with a Satellite Meeting on Legal Issues in the Conservation of Cultural Heritage, Cairo, 25 February-1 March 2007, 177.

[7] Lascaro, C. (1987) Corrosion Prevention \& Control Applications Guide.

[8] Skerry, B. (1985) How Corrosion Inhibitors Work, Corrosion Inhibitors in Conservation. In: the Proceedings of the Conference of UKIC in Association with Museum of London, The United Kingdom Institute for Conservation, London, 5-12.

[9] Jones, D.A. (1996) Principles and Prevention of Corrosion. Pearson Education, London, 5.

[10] Cole, I.S., et al. (2004) Some Recent Trends in Corrosion Science and Their Application to Conservation. Proceedings of Metal, Canberra, 2.

[11] Ikechukwu, E.E. and Pauline, E.O. (2015) Environmental Impacts of Corrosion on the Physical Properties of Copper and Aluminium: A Case Study of the Surrounding Water Bodies in Port Harcourt. Open Journal of Social Sciences, 3, 143-144. https://doi.org/10.4236/jss.2015.32019

[12] Quaranta, M. and Sandu, I. (2008) Micro-Stratigraphy of Copper-Based Archaeological Objects: Description of Degradation Mechanisms by Means of an Integrated Approach. 9th International Conference on NDT of Art, Jerusalem, 6.

[13] Korenberg, C. and Baldwin, A. (2006) Laser Cleaning Tests on Archaeological Copper Alloys Using an ND:YAG Laser. Laser Chemistry, 2006, Article ID: 75831. https://doi.org/10.1155/2006/75831

[14] Mchael, B.M. and Brenda, J.L. (1992) Corrosion Mechanisms for Copper and Silver Objects in Near-Surface Environments. Journal of the American Institute for Conservation, 31, 355-366. https://doi.org/10.2307/3179729

[15] Wan, Y., et al. (2012) Corrosion Behavior of Copper at Elevated Temperature. International Journal of Electrochemical Science, 7, 7902-7914.

[16] Shreir, L., et al. (1994) Corrosion Metal/Environment Reactions. Vol. 1, 3rd Edition, Heinemann Ltd., Butterworth, London, 4-60.

[17] Timar-Balazsy, A. and Estop, D. (1998) Chemical Principles of Textile Conservation. Butterworth-Heinemann, Oxford, 135-136.

[18] Elnaggar, A., et al. (2015) Investigation of Ultrafast Picosecond Laser System for Cleaning of Metal Decorations of 17th C. Gloves of King Charles 1. e-Preservation Science, 12, 14-19. https://doi.org/10.1186/s40494-016-0104-3

[19] Marouf, M.A. and Ghoneim, M.A. (2009) Deteriorating Effects of the Metal Threads on Embroideries: Technical and Analytical Study on Archaeological Tex- 
tiles. The Annual Meeting of the American Schools of Oriental Research, Louisiana, 90.

[20] Degrigny, C., et al. (2003) Laser Cleaning of Tarnished Silver and Copper Threads in Museum Textiles. Journal of Cultural Heritage, 4, 152-156. https://doi.org/10.1016/S1296-2074(02)01191-3

[21] Abdel-Kareem, O., et al. (2016) Evaluating Laser Cleaning of Corroded Archaeological Silver Coins. Mediterranean Archaeology and Archaeometry, 16, 135-143.

[22] Abdel-Kareem, O. and Al-Saad, Z. (2007) Conservation Strategy of Metal Embroidery Threads in Textile Objects in the Museum of Jordanian Heritage. Proceedings the International Conference on Conservation Strategies for Saving Indoor Metallic Collections with a Satellite Meeting on Legal Issues in the Conservation of Cultural Heritage, Cairo, 25 February-1 March 2007, 23.

[23] Balažic, A., et al. (2007) Extending the Useful Life of Paper-Evaluation of the Effect of Various Preservation Actions. In: Padfield, T. and Borchersen, K., Eds., The Copenhagen Conference of the Museum Microclimates, 19-23 November 2007, 39.

[24] Alten, H. (1999) How Temperature and Relative Humidity Affect Collection Deterioration Rates. Northern States Conservation Center, Haines, 2(2). https://www.collectioncare.org/pubs/v2n2p1.html

[25] Mohamed, A. (2014) Applied Studies on the Restoration and Conservation of Metal Monuments. Dar Almarefa, Cairo, 115.

[26] Ristic, S., et al. (2014) Laser Cleaning of Textile Artifacts with Metal Threads: Process Parameter Optimization. Scientific Technical Review, 64, 45-52.

[27] Koh, Y., et al. (2003) Experimental Study on the Effect of Wavelength in the Laser Cleaning of Silver Threads. Journal of Cultural Heritage, 4, 157-161. https://doi.org/10.1016/S1296-2074(02)01192-5

[28] Koh, Y. and Sárady, I. (2003) Cleaning of Corroded Iron Artifacts Using Pulsed TEA $\mathrm{CO}_{2}$ and Nd:YAG-Lasers. Journal of Cultural Heritage, 4, 129-133. https://doi.org/10.1016/S1296-2074(02)01140-8 